\section{Building Illustrated}

Being an Introduction to Standard Building Methods. By W. H. Smith. Pp. viii+112. (London: E. and F. N. Spon, Ltd., 1944.) 16s. $6 d$.

THE value of the attractive paper cover on this book has been made useless by the numerous mistakes which appear on it. For example, and here I quote from a copy of by-laws with respect to new streets and buildings: "Each external wall shall be provided with an effective damp proof course at a height of not less than six inches above the surface of the adjoining ground". The damp proof course shown on the paper cover is just over three inches above the ground-level.

The orthographic drawings have not been made in accordance with the British Standard Specification Drawing Office Practice. To give examples, the sections of Figs. 29, 82 and 86 want turning over so as to be in correct projection, and plain lines should have been used for all measurement lines instead of broken lines as shown throughout the book.

Now a word or two about windows. The pulley stile in detail $A$, Fig. 83, wants turning over so that a proper tongued and grooved joint is made.

The freakish $S$ which pervades the drawings should be avoided by students when printing the titles, as this is more often mistaken for an $F$.

There are two particularly good chapters; one is on drainage and the other on defects found in buildings.

A. S. EMERy.

\section{An Introduction to Philosophy}

By W. A. Sinclair. Pp. 152. (London, New York and Toronto : Oxford University Press, 1944.) $5 s$. net.

$\mathrm{T}$

HIS clear and well-reasoned introduction starts from the classical problem of modern philosophical thought-sense perception and the knowledge we take to be based upon it. For the scientifically trained reader this is probably the best approach, though not necessarily for other readers. By his method of treating the subject Mr. Sinclair challenges comparison with Russell's well-known "Problems of Philosophy" and survives the test very well. $\mathrm{He}$ scarcely has the lightness of touch of his predecessor, but he is rather more systematic and is better at indicating further possibilities and other inquiries. The footnote references to important thinkers are well done. The advice for further reading is refreshingly unconventional, but not well balanced; and what is said about Plato and Greek philosophy is definitely misleading.

A. D. R.

\section{Proceedings of a Conference on Problems in the} Utilisation of Small Coals

Held at the Institution of Civil Engineers, November 10th and 1lth, 1943. Pp. 294. (London: British Coal Utilisation Research Association, 1944.)

$\mathrm{T}$ is inevitable that incombustible matter accom1 panies coal arriving at the pithead and in varying degrees of association, depending on the quality of the seam. From this point follows a series of cleaning processes-dry and wet-which in general aim at the removal of dirt and fine coal. Water is usually necessary, and as a consequence the colliery must dispose of the unwanted residue of the cleaning process which contains an undesirable proportion of water. This residue, commonly known as 'slurry', consists of coal which contains too much incombustible matter; too much water and at the same time is too fine in size to have commercial value. This com- bination of physical conditions imposes such difficulties that remedial measures to convert 'slurry' into salable fuel are in normal times unremunerative ; but this is only a relative term, for the quantity of this waste of potential value is enormous-many millions of tons - which in times of scarcity is actually used. It may be that the days when this fuel can be so lightly discarded as hitherto have already passed for ever. It must be recognized that the mining industry has in the past given much attention to the problem, as will be evident from the present report on the conference on the utilization of small coals, at which twenty-eight papers were presented. These give a measure of work done, while a visit to the surface workings of a colliery will reveal the scope of the task of disposing of the wet, dirty fine coal which is produced. There is another if somewhat different problem in the disposal of fine coke.

H. J. Honsman.

\section{A Handlist of News Pamphlets, 1590-1610}

By Dr. D. C. Collins. Pp. $x x+129$. (London: South-West Essex Technical College, Walthamstow, 1943.) $10 s .6 d$.

THIS admirably produced little volume is in two parts : first, a handlist of news pamphlets printed between 1590 and 1610 and still extant; and secondly, a list of such pamphlets printed between 1590 and 1610 and entered in the Stationers' Register, but not now extant. The first list is annotated, the contents being indicated where the title is insufficient, and the comments show the significance of the item. The list is arranged chronologically, and within each year according to the date of entry in the Stationers' Register. Surviving pamphlets not entered in the Register follow the last entered copy surviving for each year. Where more than one copy of the pamphlet survives, the British Museum copy has normally been used. Other copies used are indicated by a reference letter; but the names of libraries possessing a single unique copy are given in full. If the copy for the transcript is one not recorded in the Short Title Catalogue, the press mark of the library is given. Both the Short Title Catalogue number and the date of entry of the pamphlet in the Stationers' Register and the high standard of bibliographical detail should make the list the more valuable and welcome for research into the collection and dissemination of news during the period covered. Its value and purpose in this respect are concisely explained in Dr. Collins' excellent introduction.

\section{Get to Know Yourself}

A Series of Psychological Tests. By Joseph Ralph. Pp. iv +89. (London: Chaterson, Ltd., n.d.) 3s. 6d. net.

A PART from the suggestion in the title that more A self-knowledge is desirable and a few sensible remarks here and there, this book has little to commend it. The author sets out a series of socalled self-rating 'tests' of nineteen 'dispositions'. Numerical weights, determined presumably by the author's inner consciousness, are attached to each test item. Norms suggested have an equally subjective quality. The term 'test' is certainly a misnomer for a set of overlapping and equivocal questions unstandardized or scaled in any way. The alleged 'dispositions' are nothing more than a mixed series of popular catch-phrases. No substantiation is given of the claims on behalf of the tests in the prefatory note. 